\title{
Development of Mathematics Teaching Materials Based on Realistic Mathematics Education Using Tri-N on Linear Equation System Topics
}

\author{
Rina Sri Lestari ${ }^{*}$, Akhmad Nayazik ${ }^{2}$, Lenny Kurniati ${ }^{3}$ \\ 1,2,3 Universitas Ivet \\ *rinasri718@gmail.com
}

Received: June 2021. Accepted: July 2021. Published: July 2021.

\begin{abstract}
Teaching materials are learning tools that contain materials, learning methods, and ways to evaluate students which are arranged systematically to achieve learning objectives. The teaching materials used during mathematics learning are textbooks that make it difficult for students to understand the material and educators have not developed teaching materials based on a realistic mathematics education using the Tri $N$ teaching. This research aims to determine the validity and responses of students to the development of mathematics teaching materials based on realistic mathematics education using Tri $N$ teaching on the material of linear equation system class X SMK. This type of research is Research and Development $(R \& D)$ which aims to produce and test product quality. This research refers to the $4 D$ development model, namely Define, Design, Develop, and Disseminate. However, this research only reached the development stage. Data was collected by using documentation techniques, validation sheets, and student response questionnaires. The test subjects were students of class X TKJ 1 SMK Kesuma Margoyoso. The data analysis technique used is descriptive analysis. This research produces a product of mathematics teaching materials with an average percentage of $85.6 \%$ which is included in the very valid category. Student responses to teaching materials in the very good category with an average percentage of $82.22 \%$. This shows that teaching materials are suitable for use in learning at school.
\end{abstract}

Keywords: teaching materials, realistic mathematics education, Tri $N$.

How to Cite: Lestari, R. S., Nayazik, A., \& Kurniati, L. (2021). Development of Mathematics Teaching Materials Based on Realistic Mathematics Education Using Tri-N on Linear Equation System Topics. Journal of Medives: Journal of Mathematics Education IKIP Veteran Semarang, 5(2), 363-376. 


\section{PENDAHULUAN}

Matematika merupakan ilmu universal yang mempunyai peranan penting dalam perkembangan ilmu pengetahuan dan teknologi. Melalui pembelajaran matematika siswa mulai diajarkan untuk memiliki kemampuan berpikir logis, kritis, analitis, kreatif, sistematis, serta kemampuan bekerja sama dengan orang lain dalam suatu kelompok. Pada saat pembelajaran matematika berlangsung tidak terlepas dari penggunaan bahan ajar, pendekatan pembelajaran, dan model pembelajaran. Ketiganya merupakan aspek yang saling berkaitan. Menurut Taufiq \& Agustito (2021) Pemilihan dan penggunaan bahan, pendekatan, dan model pembelajaran pasti mempertimbangkan dengan kebutuhan peserta didik.

Bahan ajar dan model pembelajaran yang sesuai dengan kondisi sekolah dan kebutuhan peserta didik akan meningkatkan keaktifan, kemandirian, dan keterampilan berpikir peserta didik, serta mendukung tercapainya tujuan pembelajaran (Fitriyana et al., 2021). Berdasarkan Surat Edaran Nomor 4 Tahun 2020 Tentang Pelaksanaan Kebijakan Pendidikan dalam Masa Darurat Penyebaran Covid-19, dijelaskan bahwa proses belajar dilaksanakan dari rumah melalui pembelajaran daring/jarak jauh untuk memberikan pengalaman belajar yang bermakna bagi siswa (Menteri Pendidikan dan Kebudayaan, 2020). Pembelajaran daring merupakan inovasi pendidikan untuk menjawab tantangan akan ketersediaan bahan ajar yang variatif.

Kemudian menurut informasi dari guru matematika SMK Kesuma
Margoyoso bahwa bahan ajar yang digunakan selama pembelajaran jarak jauh adalah buku paket. Penggunaan buku paket matematika membuat peserta didik kesulitan dalam memahami materi. Bahan ajar yang digunakan berisi uraian materi singkat, peggunaan rumus, dan latihan soal saja. Sehingga penggunaan bahan ajar ini belum optimal karena pada proses pembelajaran masih ditemukan siswa yang kebingungan ketika dihadapkan dalam mengerjakan soal yang berbeda dengan soal yang dicontohkan. Selain itu, belum pernah ada bahan ajar yang disusun oleh guru matematika dengan memperhatikan kemampuan peserta didik. Sedangkan peserta didik mempunyai kemampuan yang berbeda sehingga menyebabkan waktu yang dibutuhkan untuk memahami materi juga berbeda.

Kesulitan peserta didik dalam memahami materi dapat terjadi karena salah satu karakteristik matematika yang bersifat abstrak (Fitriyana et al., 2021). Hal ini disebabkan peserta didik belum menggunakan obyek yang ada dalam kehidupan sehari-hari dengan suatu permasalahan. Haji dalam Efuansyah \& Wahyuni (2018) menegaskan bahwa penyajian materi yang terdapat pada buku-buku matematika yang digunakan saat ini tersusun sebagai berikut: (1) Definisi, (2) Contoh soal, dan (3) Latihan soal. Penyajian materi yang berisi soalsoal saja, mengakibatkan siswa bosan belajar matematika karena materi yang diberikan terkesan monoton.

Salah satu alternatif bahan ajar yang tepat bagi peserta didik adalah modul. Modul merupakan suatu bahan ajar yang disajikan secara sistematis dan 
dirancang untuk membantu peserta didik secara individual dalam mencapai tujuan belajar. Modul dapat digunakan secara tepat dan bervariasi, seperti untuk meningkatkan motivasi belajar, mengembangkan kemampuan dalam berinteraksi dengan lingkungan belajar (Bela et al., 2021). Pengembangan modul sangat dibutuhkan dalam proses pembelajaran karena penggunaan modul matematika dapat membantu peserta didik untuk belajar lebih aktif dan mandiri atau dengan bantuan guru seminimal mungkin. Selain itu, Penggunaan modul merupakan suatu usaha mengadakan pembelajaran individual yang memungkinkan peserta didik menguasai suatu unit materi pelajaran sebelum beralih ke unit berikutnya (Taufiq \& Agustito, 2021). Sehingga mengembangkan suatu bahan ajar berupa modul matematika dapat meningkatkan minat belajar peserta didik dan mempermudah peserta didik dalam belajar (Pujiastuti et al., 2020).

Selain penggunaan bahan ajar yang tepat, perlu didukung dengan pendekatan yang sesuai agar tujuan pembelajaran yang diinginkan dapat tercapai. Bahan ajar akan lebih mudah dipahami melalui materi yang berasal dari permasalahan kehidupan seharihari. Salah satu pendekatan tersebut adalah pendekatan matematika realistik. Menurut Muhtadi \& Sukirwan (2017) Pendekatan matematika realistik berasal dari permasalahan yang ada di sekitar peserta didik dan berbasis pada pengetahuan yang dimilikinya, sehingga dapat meningkatkan pemahaman.

Pendekatan matematika realistik pada pembelajaran pada dasarnya adalah pemanfaatan realitas dan lingkungan yang dipahami peserta didik untuk memperlancar pembelajaran matematika, sehingga dapat mencapai tujuan pendidikan matematika yang lebih baik (Fitriyana et al., 2021). Realita yang dimaksud merupakan hal-hal yang nyata atau konkret, dapat diamati dan dapat dipahami peserta didik dengan membayangkan. Sedangkan lingkungan merupakan tempat peserta didik berada baik lingkungan sekolah, keluarga, dan masyarakat.

Kemudian dalam menggunakan pendekatan matematika realistik, guru berperan sebagai fasilitator yang memberi kesempatan kepada peserta didik untuk menemukan ide dan konsep matematika (Amalia et al., 2020). Pembelajaran menggunakan masalah dunia nyata sebagai suatu konteks bagi peserta didik untuk berpikir bagaimana cara memecahkan masalah, sehingga pembelajaran matematika lebih bermakna dan menyenangkan. Sejalan dengan hasil penelitian yang dilakukan oleh Yulianty (2019) pendekatan matematika realistik lebih efektif dari pada pembelajaran yang menggunakan pendekatan konvensional.

Pengembangan bahan ajar selain berbasis pendekatan matematika realistik diperlukan inovasi baru yang bertujuan untuk mendukung kebutuhan belajar peserta didik. Dalam Peraturan Menteri Pendidikan dan Kebudayaan Nomor 54 Tahun 2013 disebutkan bahwa kompetensi keterampilan peserta didik yang ingin dicapai baik jenjang pendidikan SD, SMP, dan SMA adalah memiliki kemampuan pikir dan tindak yang efektif dan kreatif (Menteri 
Pendidikan dan Kebudayaan, 2013). Salah satu inovasi baru dalam mengembangkan kreativitas adalah ajaran Ki Hajar Dewantara. Pengembangan bahan ajar dengan kearifan yang dimiliki Indonesia belum banyak ditemukan.

Salah satu ajaran Ki Hajar Dewantara yang dapat digunakan untuk mengembangkan bahan ajar adalah ajaran Tri N (niteni, nirokke, nambahi). Menurut Daen et al. (2020) Niteni (mengamati) dimana peserta didik memperhatikan, mengamati, membaca atau mendengarkan dengan teliti, meraba, dan merasakan dengan panca indranya. Nirokke (meniru) dimana peserta didik mencontoh, menirukan, melakukan sesuatu yang sama dengan sesuatu yang diamati. Sedangkan Nambahi (menambahkan) dimana peserta didik berusaha menambahkan, menyesuaikan, melakukan perubahan, atau mengurangi model yang ditiru sesuai dengan kreativitas masingmasing. Menurut Yunianto dalam Taufiq \& Agustito (2021) Tri N merupakan metode yang sistematik, berseri, dan bertahap sehingga tidak boleh saling mendahului agar memperoleh pengetahuan dan keterampilan yang lengkap.

Tri N mengandung nilai-nilai dalam proses pembentukan kreativitas sehingga ajaran ini dapat digunakan dalam pengembangan kreativitas. Sejalan dengan hasil penelitian Budiati et al. (2018) Penerapan Tri N pada pembelajaran matematika dapat mengembangkan kreativitas dalam menyelesaikan permasalahan dan meningkatkan keaktifan peserta didik. kemudian Ardhyantama (2020) menegaskan bahwa gagasan Tri $\mathrm{N}$ dapat menjadi faktor pendorong kreativitas dan prosesnya menjadikan gagasan ini cocok digunakan sebagai pedoman dalam pengembangan kreativitas. Taufiq \& Agustito (2021), serta Kuncoro \& Arigiyati (2020) telah mengembangkan modul berbasis ajaran Ki Hajar Dewantara. Selain itu, modul berbasis pendekatan matematika realistik juga telah dikembangkan oleh Efuansyah \& Wahyuni (2018), Chuseri et al. (2021), serta Fitriyana et al. (2021). Namun sampai saat ini belum ada yang meneliti pengembangan modul berbasis pendekatan matematika realistik menggunakan ajaran Tri N.

Beberapa uraian sebelumnya, menunjukkan bahwa pengembangan bahan ajar berbasis pendekatan matematika realistik menggunakan ajaran Tri $\mathrm{N}$ merupakan inovasi baru. Adanya pengembangan bahan ajar ini diharapkan dapat meningkatkan pola berpikir kritis, kreatif, dan inovatif dalam menyelesaikan suatu masalah, serta memudahkan peserta didik dalam memahami materi. Selain itu, penelitian ini dapat dijadikan sebagai sumber referensi bagi pendidik dalam mengembangkan modul.

Berdasarkan uraian di atas rumusan masalah dari penelitian ini adalah sebagai berikut. (1) Bagaimana pengembangan bahan ajar berbasis pendekatan matematika realistik menggunakan ajaran Tri $\mathrm{N}$ pada materi sistem persamaan linear kelas X SMK yang valid. (2) Bagaimana respon peserta didik terhadap bahan ajar berbasis pendekatan matematika realistik menggunakan ajaran Tri $\mathrm{N}$ pada materi sistem persamaan linear kelas X SMK. 


\section{METODE PENELITIAN}

Jenis penelitian ini adalah penelitian dan pengembangan atau Research and Development (R\&D) yang digunakan untuk menghasilkan produk (prototype) dan menguji kualitas produk tersebut (Efuansyah \& Wahyuni, 2018). Model penelitian pengembangan yang digunakan adalah model 4D yang terdiri dari 4 tahap yaitu Define, Design, Develop, dan Disseminate yang dikembangkan oleh Thiagarajan (Kurniawan \& Dewi, 2017). Subyek penelitian ini adalah siswa kelas X TKJ 1 SMK Kesuma Margoyoso sebanyak 9 orang yang mewakili kemampuan akademik tinggi, sedang, dan rendah.

Teknik pengumpulan data yang digunakan adalah dokumentasi, lembar validasi, dan angket respon peserta didik. Analisis data yang digunakan pada tahap define adalah analisis deskriptif kualitatif, pada tahap design adalah analisis deskriptif, Sedangkan pada tahap develop adalah analisis deskriptif kuantitatif dengan skala likert (Sugiyono, 2015).

\section{HASIL DAN PEMBAHASAN}

Penelitian ini menghasilkan produk bahan ajar berupa modul matematika berbasis pendekatan matematika realistik menggunakan ajaran Tri N. Konten materinya yaitu sistem persamaan linear untuk SMK Kelas X. Penelitian ini dilaksanakan sesuai dengan prosedur pengembangan yaitu define, design, develop, dan disseminate. Namun pada penelitian ini hanya sampai pada tahap develop.

\section{Define (Pendefinisian)}

Pada tahap define dilakukan pengumpulan informasi-informasi yang berkaitan dengan produk yang akan dikembangkan. Hal ini bertujuan untuk menetapkan dan mengidentifikasi syarat-syarat pembelajaran. Pada tahap ini yang dilakukan yaitu analisis kurikulum, analisis materi, dan merumuskan tujuan pembelajaran. Berdasarkan hasil analisis, kurikulum yang berlaku yaitu kurikulum 2013 dan materi sistem persamaan linear merupakan materi SMK kelas X semester ganjil. Kemudian materi sistem persamaan linear dikaji kompetensi dasar dan indikatornya. Hasil kajian tersebut digunakan sebagai pedoman dalam pengembangan bahan ajar matematika. Berdasarkan materi, kompetensi dasar dan indikator yang telah ditetapkan, dapat digunakan dalam merumuskan tujuan pembelajaran. Adapun tujuan pembelajaran materi sistem persamaan linear dapat dilihat pada Tabel 1.

Tabel 1. Tujuan Pembelajaran

\begin{tabular}{l}
\hline \multicolumn{3}{c}{ Tujuan Pembelajaran } \\
\hline 1. Memahami persamaan linear dua \\
variabel. \\
2. Memahami persamaan linear tiga \\
variabel. \\
3. Membuat bentuk sistem persamaan \\
linear dua variabel. \\
4. Membuat bentuk sistem persamaan \\
linear tiga variabel. \\
5. Menentukan himpunan penyelesaian \\
sistem persamaan linear dua variabel. \\
6. Menentukan himpunan penyelesaian \\
sistem persamaan linear tiga variabel. \\
7. Menyelesaikan sistem persamaan linear \\
dua variabel dari masalah kontekstual. \\
8. Menyelesaikan sistem persamaan linear \\
tiga variabel dari masalah kontekstual.
\end{tabular}




\section{Design (Perancangan)}

Tahap design bertujuan untuk merancang prototype bahan ajar berbasis pendekatan matematika realistik menggunakan ajaran Tri $\mathrm{N}$ berdasarkan kompetensi dasar, indikator, dan tujuan pembelajaran yang telah ditetapkan. Komponen bahan ajar yaitu cover depan, kata pengantar, daftar isi, deskripsi modul, petunjuk penggunaan modul, kompetensi inti, kompetensi dasar, indikator, tujuan pembelajaran, peta konsep, tokoh matematika, materi, contoh soal, latihan soal, rangkuman, uji kompetensi, glosarium, daftar pustaka, biodata penulis, dan cover belakang.

Bahan ajar dibuat dengan bantuan CorelDraw pada bagian cover depan, cover belakang, dan ilustrasi gambar. Hal ini dilakukan untuk menghasilkan ilustrasi yang baik dan menarik. Sehingga peserta didik tidak merasa bosan ketika belajar, sedangkan bagian materi dibuat dengan bantuan Microsoft word. Setiap lembar bahan ajar dilengkapi dengan nomor halaman agar peserta didik lebih mudah dalam menemukan materi yang dipelajari. Ukuran kertas bahan ajar yang dipakai yaitu A4 yang terdiri dari 57 halaman. Setelah bahan ajar dibuat, langkah selanjutnya adalah mengubah format file menjadi bentuk pdf (Portable Document Format). Hal ini dilakukan untuk memudahkan dalam penggunaan dan penyebaran. Karena dengan format $p d f$ bisa dibuka dengan media apapun dan oleh siapapun. Bahan ajar ini dapat digunakan dalam pembelajaran online maupun offline.

Design cover dibuat dengan memadukan warna orange, kuning, biru, putih, dan hitam dengan tujuan menarik minat peserta didik.

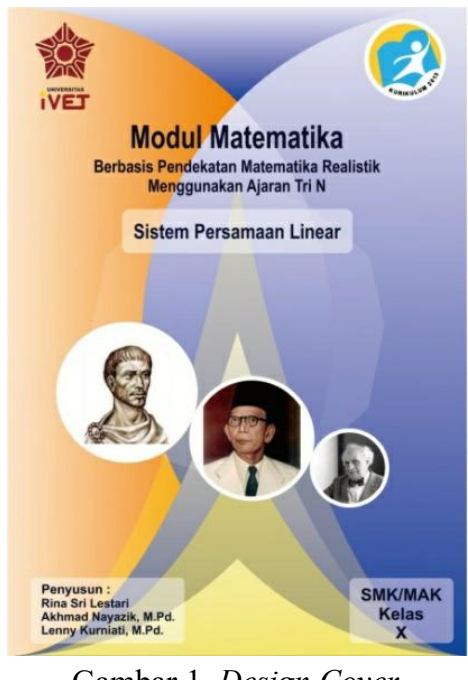

Gambar 1. Design Cover

Design dari bagian niteni dibuat dengan menyajikan materi dan contoh soal yang berkaitan dengan kehidupan sehari-hari beserta cara penyelesainnya. Peserta didik dapat menyelesaikan contoh soal dengan mengikuti petunjuk yang ada sesuai dengan langkah pendekatan matematika realistik.

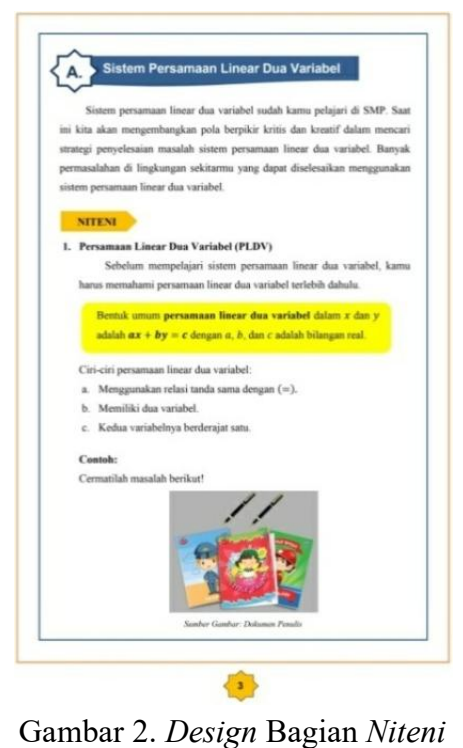

Gambar 2. Design Bagian Niteni 
Design dari bagian nirokke dibuat dengan menyajikan soal yang mirip dengan bagian niteni dan shape kosong untuk menyelesaikan soal.

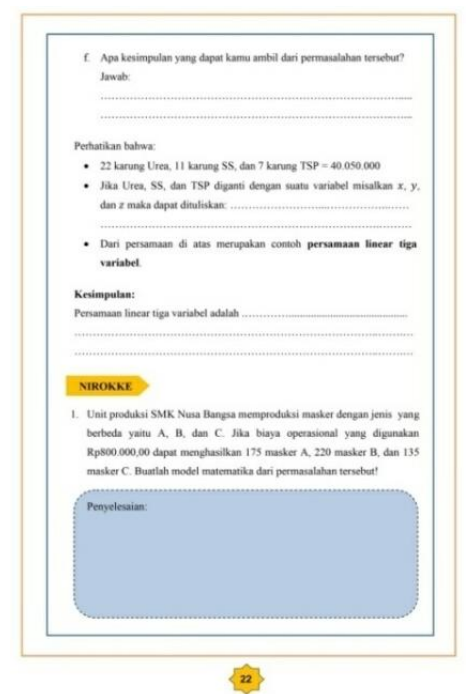

Gambar 3. Design Bagian Nirokkke

Sedangkan design dari bagian nambahi dibuat dengan menyajikan soal dengan tingkat kesulitan yang lebih tinggi dari bagian nirokke yang menuntut peserta didik untuk berpikir kreatif dan terdapat shape kosong sebagai tempat untuk menyelesaikan soal tersebut.

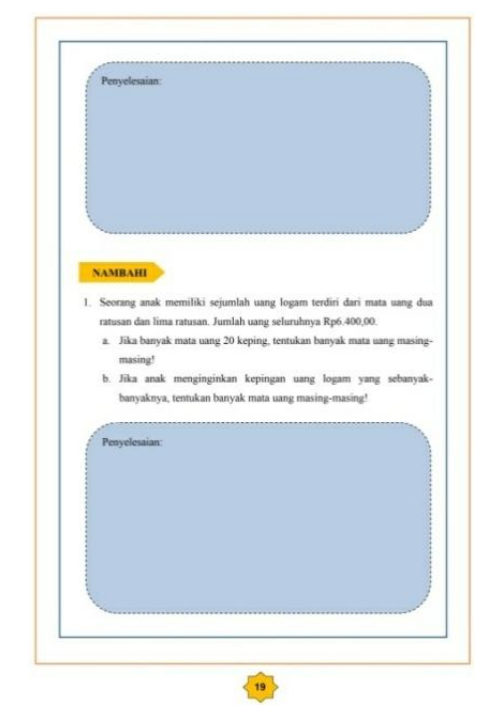

Gambar 4. Design Bagian Nambahi

\section{Develop (Pengembangan)}

Pada tahap develop bahan ajar yang telah dibuat kemudian divalidasi dan di uji cobakan pada peserta didik untuk memperoleh penilaian terkait dengan kelayakan produk.

\section{Validasi Ahli}

Bahan ajar matematika yang sudah dibuat kemudian divalidasi oleh ahli. Validasi bertujuan untuk memperoleh penilaian yang berkaitan dengan kevalidan materi, penyajian, dan bahasa. Validator terdiri dari 8 orang di antaranya 4 ahli di bidang pendidikan matematika dan 4 ahli praktisi pendidikan matematika. Dari validasi bahan ajar diperoleh penilaian secara kuantitatif dan kualitatif. Penilaian tersebut kemudian digunakan untuk memperbaiki bahan ajar matematika.

Penilaian secara kuantitatif diperoleh skor validasi dari setiap item. Adapun hasil perhitungan validasi dapat dilihat pada Tabel 2.

Tabel 2. Hasil Validasi Ahli

\begin{tabular}{ccl}
\hline No. Item & Persentase & Kategori \\
\hline 1. & $82,5 \%$ & Sangat Valid \\
2. & $85 \%$ & Sangat Valid \\
3. & $95 \%$ & Sangat Valid \\
4. & $87,5 \%$ & Sangat Valid \\
5. & $80 \%$ & Valid \\
6. & $90 \%$ & Sangat Valid \\
7. & $82,5 \%$ & Sangat Valid \\
8. & $92,5 \%$ & Sangat Valid \\
9. & $90 \%$ & Sangat Valid \\
10. & $87,5 \%$ & Sangat Valid \\
11. & $80 \%$ & Valid \\
12. & $80 \%$ & Valid \\
13. & $90 \%$ & Sangat Valid \\
14. & $82,5 \%$ & Sangat Valid \\
15. & $75 \%$ & Valid \\
16. & $90 \%$ & Sangat Valid \\
17. & $82,5 \%$ & Sangat Valid \\
18. & $87,5 \%$ & Sangat Valid \\
Rata-rata & $85,6 \%$ & Sangat Valid \\
\hline
\end{tabular}


Berdasarkan Tabel 2 diperoleh rata-rata persentase kevalidan $85,6 \%$ maka berada pada kategori sangat valid. Selain penilaian tersebut, validator juga memberikan penilaian secara kualitatif dalam bentuk komentar dan saran untuk memperbaiki bahan ajar.

Berkaitan dengan kelayakan isi dari validator menyampaikan bahwa materi disajikan secara lengkap, akurat, dan sesuai dengan tujuan pembelajaran yang hendak dicapai serta menggunakan ilustrasi yang relevan. Berkaitan dengan penyajian, ajaran Tri $\mathrm{N}$ pada bahan ajar matematika sudah disajikan secara konsisten. Sedangkan pada aspek kebahasaan dari ahli matematika menyampaikan bahwa bahan ajar menggunakan bahasa yang sesuai kaidah Ejaan Yang Disempurnakan (EYD) dan dapat dipahami dengan baik oleh peserta didik SMK/MAK kelas X. Namun ada beberapa saran dari validator yang menjadi pertimbangan bagi peneliti untuk memperbaiki bahan ajar. Sehingga diperoleh kesimpulan bahwa bahan ajar matematika valid dengan perbaikan.

Pertama, pada bagian niteni proses penyelesaian contoh soal belum disajikan secara rinci sesuai dengan karakteristik pendekatan matematika realistik. Oleh karena itu, diperbaiki dengan menambah langkah membandingkan jawaban dan menyimpulkan solusi yang diperoleh agar peserta didik saling berinteraksi antara satu sama lain. Revisi yang sudah dilakukan dapat dilihat pada Gambar 6.

Kedua, soal yang diberikan pada bagian nambahi belum mengakomodir kecakapan personal peserta didik sehing-

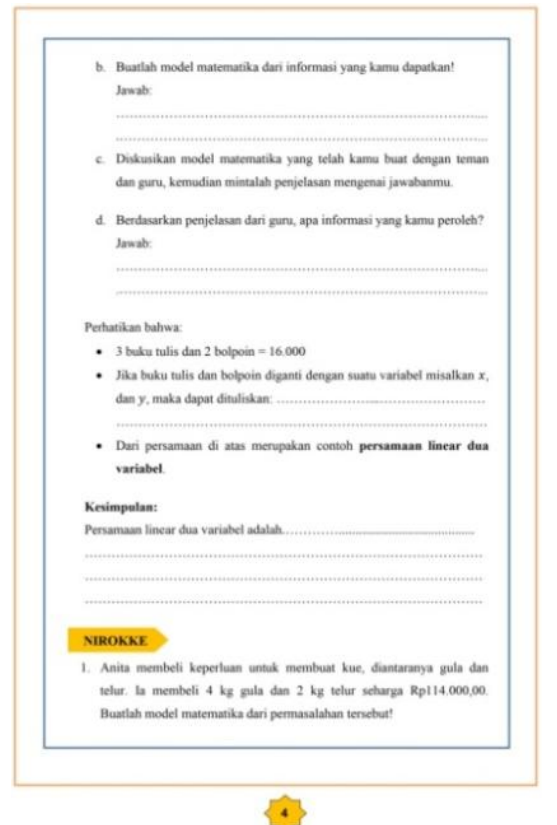

Gambar 5. Tampilan Bagian Niteni Sebelum Revisi

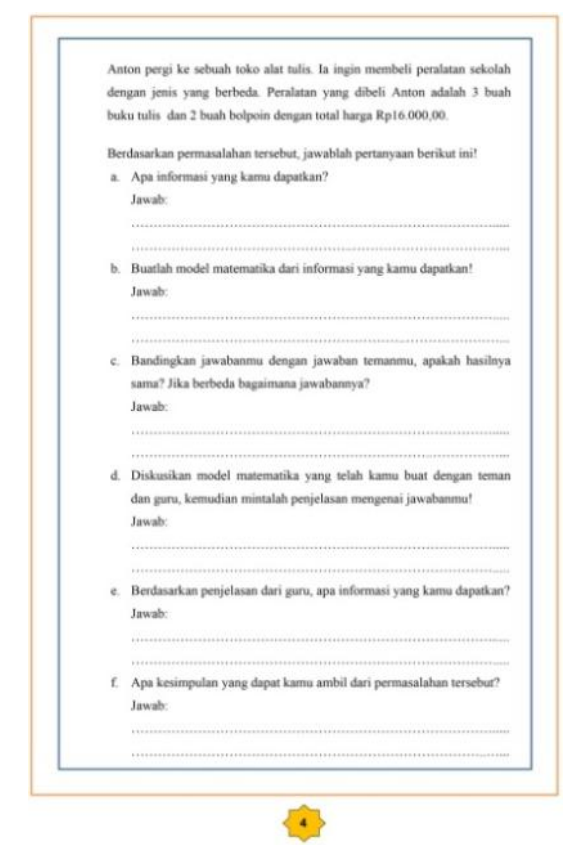

Gambar 6. Tampilan Bagian Niteni Sesudah Revisi

ga soal pada bagian nambahi diperbaiki dengan memunculkan ide baru agar peserta didik dapat berpikir lebih kritis. Selain itu peserta didik diminta untuk 
memberikan alasan atas jawaban yang diberikan dengan menyer-takan pertanyaan "Bagaimana". Revisi yang sudah dilakukan dapat dilihat pada Gambar 8.

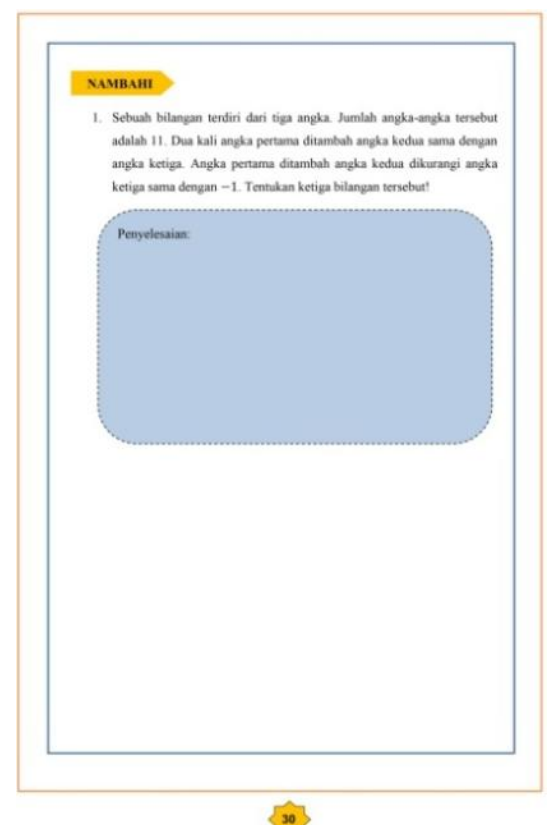

Gambar 7. Tampilan Bagian Nambahi Sebelum Revisi

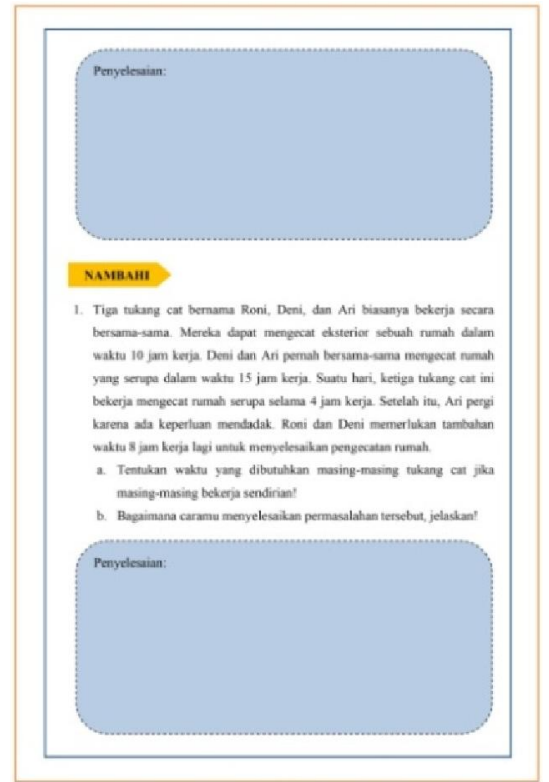

[4]

Gambar 8. Tampilan Bagian Nambahi Sesudah Revisi
Ketiga, grafik sistem persamaan linear dua variabel pada bagian garis $x$ dan $y$ tidak jelas. Oleh karena itu, grafik penyelesian sistem persamaan linear dua variabel diperbaiki dengan menunjukkan garis $x$ dan $y$. Revisi yang sudah dilakukan dapat dilihat pada Gambar 9.

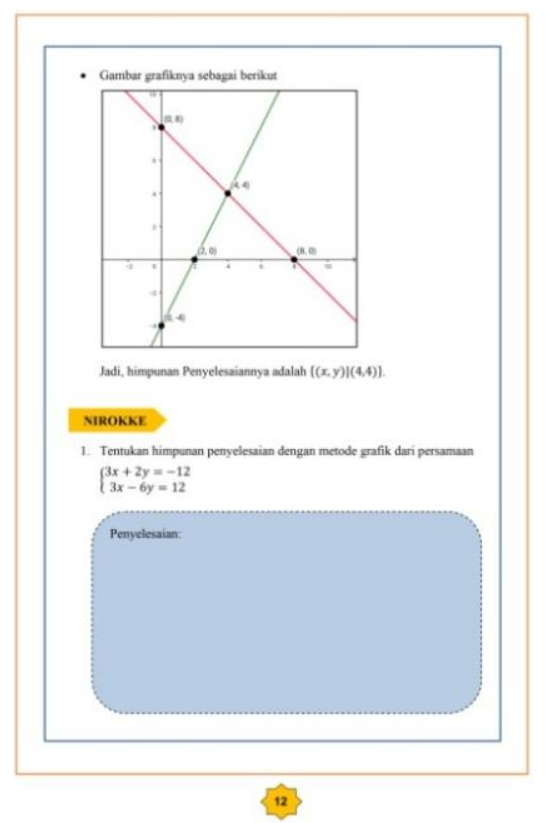

Gambar 9. Tampilan Grafik Sebelum Revisi

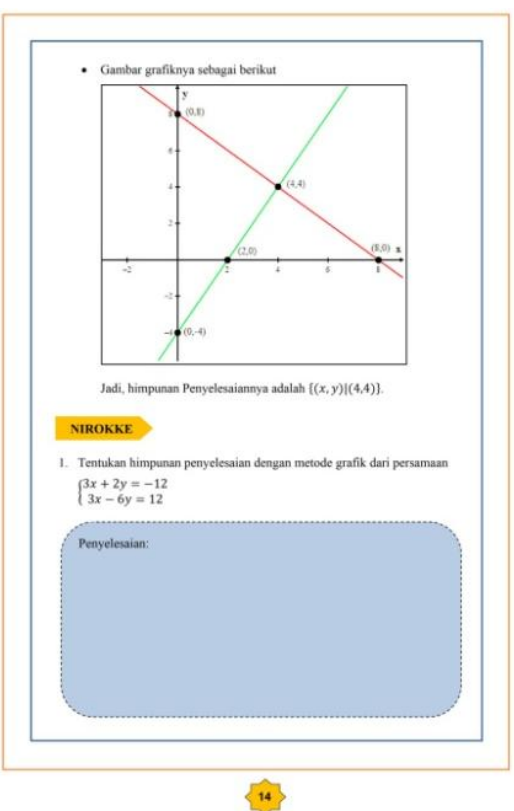

Gambar 10. Tampilan Grafik Sesudah Revisi 
Keempat, penggunaan kata ganti tidak konsisten. Kata ganti yang digunakan yaitu kamu, kalian, dan anda. Sehingga perlu diperbaiki dengan memilih kata ganti "kamu". Revisi yang sudah dilakukan dapat dilihat pada Gambar 12.

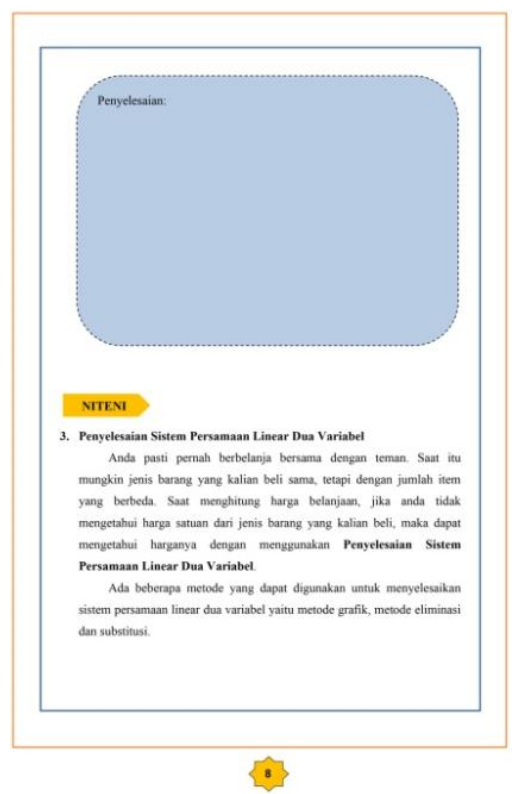

Gambar 11. Tampilan Kata Ganti Sebelum Revisi

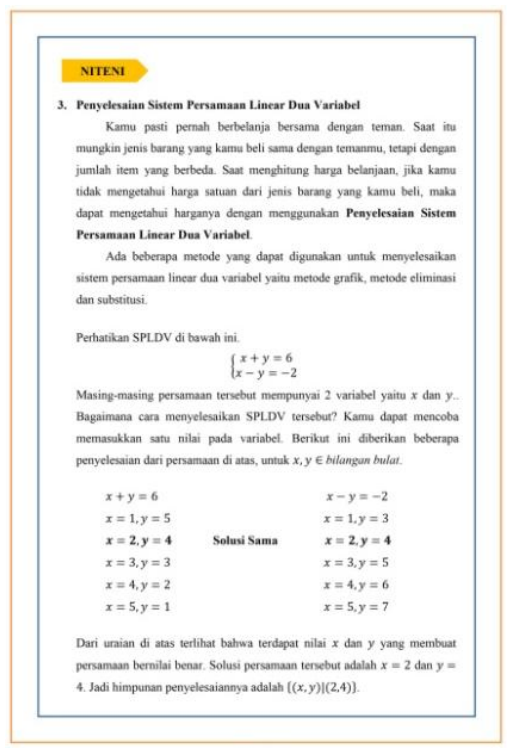

10

Gambar 12. Tampilan Kata Ganti Sesudah Revisi
Kelima, penggunaan equation belum lengkap. Oleh karena itu, equation dilengkapi dengan memberikan tanda ekuivalensi pada penyelesaian contoh soal. Revisi yang sudah dilakukan dapat dilihat pada Gambar 14.

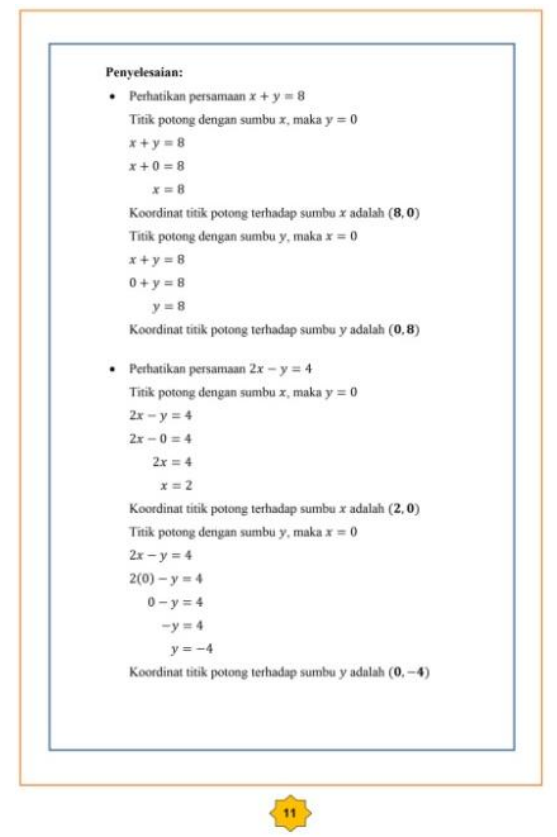

Gambar 13. Tampilan Equation Sebelum Revisi

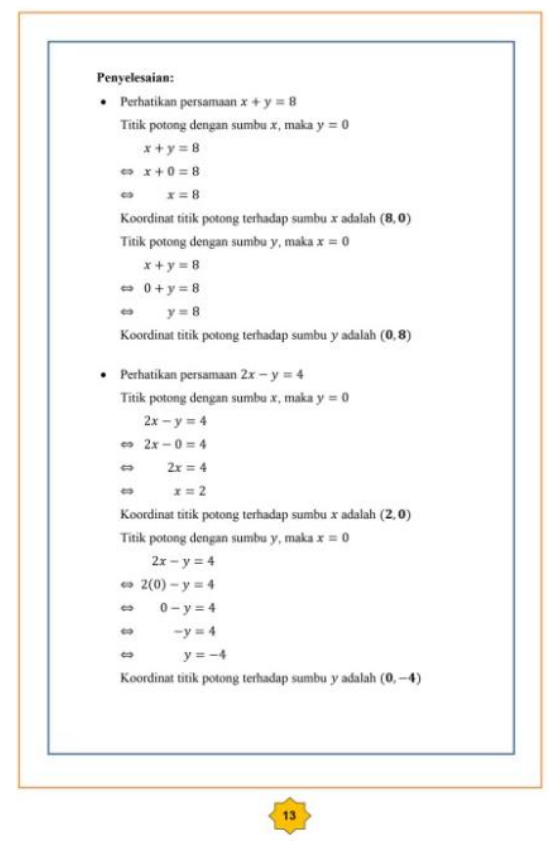

Gambar 14. Tampilan Equation Sesudah Revisi 
Keenam, pada bagian glosarium ada pendefinisian konsep yang belum sesuai di antaranya definisi persamaan linear. Sehingga definisi persamaan linear dijelaskan secara mendetail agar mudah dipahami peserta didik. Revisi yang sudah dilakukan dapat dilihat pada Gambar 16.

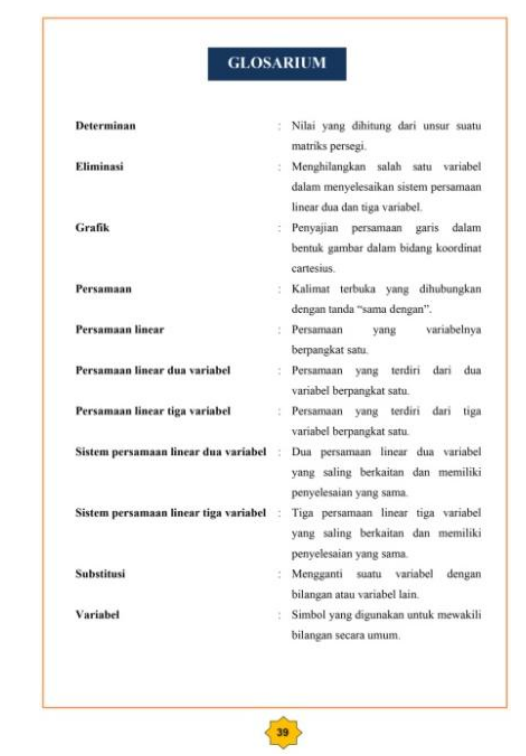

Gambar 15. Tampilan Glosarium Sebelum Revisi

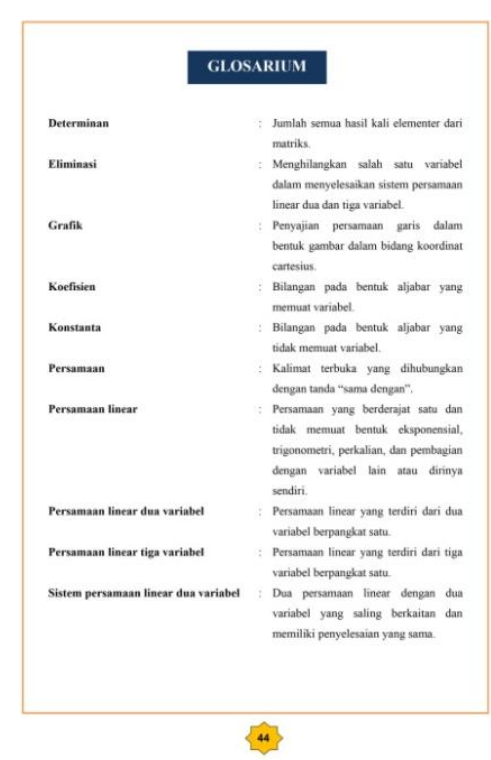

Gambar 15. Tampilan Glosarium Sesudah Revisi

\section{Uji Coba Produk}

Setelah bahan ajar dinyatakan valid dan revisi sudah dilaksanakan, maka dapat di ujicobakan kepada peserta didik. Uji coba dilaksanakan untuk mengetahui respon peserta didik terhadap bahan ajar yang sudah dikembangkan. Uji coba dilaksanakan secara terbatas, dimana peserta didik mengisi angket/kuesioner. Pelaksanaan uji coba di SMK Kesuma Margoyoso dengan subyek kelas $\mathrm{X}$ TKJ 1 yang berjumlah 9 peserta didik. Dari angket yang sudah diisi didapatkan data kualitatif kemudian dikonversikan ke dalam data kuantitatif. Adapun hasil perhitungan angket respon peserta didik dapat dilihat pada Tabel 3 .

\begin{tabular}{ccc}
\multicolumn{3}{c}{ Tabel 3. Hasil Angket Respon Peserta Didik } \\
\hline No. Item & Persentase & Kategori \\
\hline 1. & $88,89 \%$ & Sangat Baik \\
2. & $77,78 \%$ & Baik \\
3. & $75,56 \%$ & Baik \\
4. & $80 \%$ & Baik \\
5. & $82,22 \%$ & Sangat Baik \\
6. & $93,33 \%$ & Sangat Baik \\
7. & $91,11 \%$ & Sangat Baik \\
8. & $93,33 \%$ & Sangat Baik \\
9. & $82,22 \%$ & Sangat Baik \\
10. & $73,33 \%$ & Baik \\
11. & $75,56 \%$ & Baik \\
12. & $82,22 \%$ & Sangat Baik \\
13. & $93,33 \%$ & Sangat Baik \\
14. & $91,11 \%$ & Sangat Baik \\
15. & $75,56 \%$ & Baik \\
16. & $75,56 \%$ & Baik \\
17. & $77,78 \%$ & Baik \\
18. & $71,11 \%$ & Baik \\
19. & $75,56 \%$ & Baik \\
20. & $88,89 \%$ & Sangat Baik \\
Rata-rata & $82,22 \%$ & Sangat Baik \\
\hline
\end{tabular}

Berdasarkan Tabel 3 diketahui bahwa rata-rata persentase angket respon peserta didik yaitu $82,22 \%$ maka berada pada kategori sangat baik. Kemudian peserta didik memberikan komentar dan 
saran bahwa penggunaan bahan ajar matematika dalam pembelajaran sangat menarik, karena berisi contoh soal dalam kehidupan sehari-hari yang mudah dipahami. Selain itu bahan ajar matematika dilengkapi dengan gambar yang berkaitan dengan materi sehingga menarik perhatian peserta didik untuk belajar. Bapak/Ibu guru belum pernah menggunakan bahan ajar berbentuk modul pada saat pembelajaran sehingga peserta didik mempunyai pengalaman baru dalam belajar. Adanya ajaran Tri $\mathrm{N}$ dalam bahan ajar matematika sangat unik, karena peserta didik belum pernah menemui bahan ajar berbasis Tri N. Sehingga bahan ajar berbasis pendekatan matematika realistik menggunakan ajaran Tri $\mathrm{N}$ pada materi sistem persamaan linear layak digunakan pada pembelajaran.

Hasil tersebut selaras dengan penelitian yang dilakukan oleh Chuseri et al. (2021) mengenai pengembangan modul berbasis matematika realistik. Materi dalam modul berisi persoalan yang dekat dengan kehidupan siswa, dan pembahasannya menggunakan hal-hal konkret berupa aktivitas untuk menjembatani siswa dalam memahami konsep. Penilaian dari ahli media sebesar 3,20 dan ahli materi 3,65 termasuk dalam kategori sangat valid. Respon peserta didik memperoleh rata-rata 3,40 termasuk dalam kategori sangat praktis. Oleh karena itu modul matematika layak digunakan sebagai pegangan siswa dalam belajar.

Penelitian yang sama dilakukan oleh Kuncoro \& Arigiyati (2020) mengenai pengembangan modul elektronik berbasis Tri $\mathrm{N}$ yang berisi materi secara detail dan contoh soal yang bervariasi. Hal ini bertujuan untuk menerapkan konsep pembelajaran yang melibatkan siswa sehingga tidak merasa bosan dan malas belajar. Hasil validasi ahli 4,23 dengan skala 5 termasuk dalam kategori sangat baik. Maka modul elektronik dinyatakan valid dan dapat digunakan pada pembelajaran.

\section{PENUTUP}

Berdasarkan penelitian yang dilakukan menghasilkan produk bahan ajar berupa modul matematika berbasis pendekatan matematika realistik menggunakan ajaran Tri $\mathrm{N}$ pada materi sistem persamaan linear kelas X SMK dengan tahapan define, design, dan develop. Kevalidan bahan ajar matematika menurut 8 validator dengan rata-rata persentase $85,6 \%$ pada kategori sangat valid. Sedangkan respon peserta didik terhadap bahan ajar matematika pada kategori sangat baik dengan ratarata persentase $82,22 \%$. Sehingga bahan ajar matematika layak digunakan pada proses pembelajaran di sekolah baik secara online maupun offline. Prosedur penelitian yang dilakukan hanya sampai pada tahap develop. Dengan demikian, bahan ajar matematika ini dapat digunakan untuk tahap selanjutnya yaitu disseminate (penyebaran).

\section{DAFTAR PUSTAKA}

Amalia, A. R., Purwati, H., \& Nursyahidah, F. (2020). Pengembangan Media Pembelajaran Berbasis PMRI untuk Meningkatkan Kemampuan Berpikir Kritis Siswa SMP. Imajiner: Jurnal Matematika dan Pendidikan Matematika, 2(4), 321-328. 
Ardhyantama, V. (2020). Pengembangan Kreativitas Berdasarkan Gagasan Ki Hajar Dewantara. Jurnal Pendidikan dan Kebudayaan, 5(1), 73-86.

Bela, M. E., Wewe, M., \& Lengi, S. (2021). Pengembangan Modul Matematika Materi Aritmatika Sosial Berbasis Pendekatan Saintifik untuk Siswa Kelas VII SMP. Jurnal Cendekia: Jurnal Pendidikan Matematika, 05(01), 391-400.

Budiati, N., Istiqomah, Purnami, A. S., \& Agustito, D. (2018). Penerapan konsep 3N (niteni, nirokke, nambahi) dalam pembelajaran matematika. Prosiding Seminar Nasional Pendidikan Matematika Etnomatnesia. Yogyakarta: Program Studi Pendidikan Matematika Universitas Sarjanawiyata Tamansiswa.

Chuseri, A., Anjarini, T., \& Purwoko, R. Y. (2021). Pengembangan Modul Matematika Berbasis Realistik Terintegrasi Higher Order Thinking Skills (HOTS) Pada Materi Bangun Ruang. Jurnal Pendidikan dan Pembelajaran Matematika, 3(1), 18-31.

Daen, N., Istiqomah, \& Arigiyati, T. A. (2020). Model Pembelajaran Group Investigation dengan Pendekatan 3N untuk Meningkatkan Motivasi dan Hasil Belajar Matematika. UNION: Jurnal Pendidikan Matematika, 8(3), 319-332.

Efuansyah, E., \& Wahyuni, R. (2018). Pengembangan Bahan Ajar Matematika Berbasis PMRI Pada Materi Kubus dan Balok Kelas VIII. Jurnal Derivat: Jurnal Matematika dan Pendidikan Matematika, 5(2), 28-41.
Fitriyana, Z. N., Mailizar, \& Seruni. (2021). Pengembangan Modul Pembelajaran Matematika dengan Pendekatan Matematika Realistik. Jurnal Kajian Pendidikan Matematika, 6(2), 279-292.

Kuncoro, K. S., \& Arigiyati, T. A. (2020). Development of 3NOriented TPACK (Technology Pedagogy and Content Knowledge) Mathematical Computing E- Modules. JIPM (Jurnal Ilmiah Pendidikan Matematika), 8(2), 122-130.

Kurniawan, D., \& Dewi, S. V. (2017). Pengembangan Perangkat Pembelajaran Dengan Media Screencast-O-Matic Mata Kuliah Kalkulus 2 Menggunakan Model 4-D Thiagarajan. Jurnal Siliwangi, 3(1), 214-219.

Menteri Pendidikan dan Kebudayaan. (2013). Peraturan Menteri Pendidikan dan Kebudayaan Republik Indonesia Nomor 54 Tahun 2013 Tentang Standar Kompetensi Lulusan Pendidikan Dasar dan Menengah.

Menteri Pendidikan dan Kebudayaan. (2020). Surat Edaran Nomor 4 Tahun 2020 Tentang Pelaksanaan Kebijakan Pendidikan Dalam Masa Darurat Penyebaran COVID-19.

Muhtadi, D., \& Sukirwan, S. (2017). Implementasi Pendidikan Matematika Realistik (PMR) untuk Meningkatkan Kemampuan Berpikir Kreatif Matematik dan Kemandirian Belajar Peserta Didik. Mosharafa: Jurnal Pendidikan Matematika, 6(1), 112.

Pujiastuti, H., Haryadi, R., \& Ridwan, F. (2020). Development of Mathematics Teaching Materials 
376 | Rina Sri Lestari, Akhmad Nayazik, Lenny Kurniati - Development of Mathematics Teaching Materials Based on ....

Based On Scientific Approach for Mathematics Learning. AKSIOMA: Jurnal Program Studi Pendidikan Matematika, 9(3), 591-600.

Sugiyono. (2015). Metode Penelitian Kuantitatif, Kualitatif, dan $R \& D$. Bandung: Alfabeta.

Taufiq, I., \& Agustito, D. (2021). Uji Kelayakan Modul Trigonometri Berbasis Ajaran Tamansiswa. Mosharafa: Jurnal Pendidikan Matematika, 10(2), 281-290.

Yulianty, N. (2019). Kemampuan Pemahaman Konsep Matematika Siswa dengan Pendekatan Pembelajaran Matematika Realistik. Jurnal Pendidikan Matematika Raflesia, 4(1), 60-65. 